\title{
Polityczne uwarunkowania wschodnioazjatyckiego modelu rozwoju: ustrój, instytucje i warunki zewnętrzne
}

\begin{abstract}
Streszczenie: Artykuł analizuje polityczne uwarunkowania wschodnioazjatyckiego modelu rozwoju, skupiając się na ustroju politycznym, instytucjach oraz warunkach zewnętrznych. Model ów odpowiada za spektakularne osiągnięcia rozwojowe niektórych państw Azji Wschodniej i opiera się na koncepcji państwa rozwojowego, którego głównym celem jest nadrabianie zaległości rozwojowych wobec państw wysoko rozwiniętych. Analiza ma za zadanie odpowiedzenie na pytanie dotyczące preferowanego typu ustroju politycznego dla realizacji celów państwa rozwojowego, określenie kluczowych dla jego funkcjonowania instytucji oraz opisanie specyficznych zewnętrznych warunków politycznych.

W toku analizy stwierdzono, iż koncepcję można wprowadzić zarówno w państwach o ustroju demokratycznym, jak i autorytarnym. Państwo autorytarne może posiadać lepsze środowisko polityczne dla celów państwa rozwojowego, niemniej jednak sam system polityczny ma znaczenie drugorzędne. Kluczowe są natomiast odpowiednie i dobrze funkcjonujące instytucje, takie jak prawa własności i umiejętność korygowania nieprawidłowości w funkcjonowaniu rynku. Państwo rozwojowe jest państwem silnym, zdolnym do zmobilizowania społeczeństwa i sektora biznesowego na rzecz celów rozwojowych. Jego pozycja jest częściowo wynikiem uwarunkowań zewnętrznych. Historyczne państwa rozwojowe powstały w okresie zimnej wojny, a sytuacja międzynarodowa ułatwiała mobilizację społeczeństwa i zapewniała wsparcie polityczne i gospodarcze Stanów Zjednoczonych.
\end{abstract}

Słowa kluczowe: rozwój, ustrój polityczny, instytucje, Azja Wschodnia

\section{Wstęp}

1 schodnioazjatycki model rozwoju opiera się na koncepcji państwa rozwojowego (ang. developmental state). Wielu badaczy uważa, iż polityka rozwojowa i rozwiązania instytucjonalne ujęte w ramy koncepcji państwa rozwojowego są bezpośrednio odpowiedzialne za spektakularną dynamikę rozwojową Japonii, Korei Południowej oraz Tajwanu w drugiej połowie XX w. W szczególności warty uwagi jest tutaj przykład Korei Południowej, której poziom rozwoju po wojnie koreańskiej (1950-1953) był porównywalny z ubogimi państwami Afryki Subsaharyjskiej, a obecnie to państwo o jednej z najlepiej rozwiniętych gospodarek na świecie ${ }^{1}$.

Koncepcja państwa rozwojowego została w literaturze przedmiotu przeanalizowana bardzo szczegółowo, z zastosowaniem różnych perspektyw i ujęć. Analizie poddano uwarunkowania polityczne, gospodarcze i społeczne, cechy polityki państwa, warunki zewnętrzne oraz infrastrukturę instytucjonalną. Istnieje konsensus, co do głównych

${ }^{1}$ Aby lepiej zrozumieć procesy zachodzące w Korei Południowej w okresie tzw. szybkiego wzrostu należy zacząć od lektury Alice H. Amsden, pt. Asia's Next Giant: South Korea and Late Industrialization. 
jej cech, natomiast nie ma zgody co do ich kategoryzacji. Przykładowo, Weiss (2000) rozróżnia trzy główne kryteria, na podstawie których można określić, czy dany organizm państwowy wykazuje cechy zbliżone do tych zawartych w koncepcji: efektywne nadrabianie zaległości rozwojowych i zmniejszanie luki cywilizacyjnej wobec państw wysoko uprzemysłowionych jako absolutny priorytet państwa, organizacja administracji państwowej, którą cechuje autonomia oraz funkcjonowanie agencji pilotującej, nadzorującej i odpowiedzialnej za rozwój społeczno-gospodarczy, instytucjonalne związki pomiędzy administracją a zorganizowanymi aktorami sektora biznesowego, jako inkubatory polityki ekonomicznej państwa oraz platformy do jej negocjacji i implementacji. Stubbs (2009) rozróżnia trzy główne składniki koncepcji: pierwszy, to spójny zbiór instytucji posiadających zdolność do wdrażania zaplanowanej strategii wzrostu gospodarczego w warunkach systemu kapitalistycznego, drugi, to tzw. aspekty relacyjne (ang. relational aspects), czyli te, które podkreślają znaczenie interakcji pomiędzy aktorami występującymi w ramach organizmu państwowego w wymiarze politycznym, gospodarczym i społecznym. Ta interakcja ma miejsce poprzez płynną (ang. seamless) sieć wzajemnych powiązań i wpływów. Trzeci, to kwestie ideowe, a raczej ich amalgamat, w szczególności nacjonalizmu, neomerkantylizmu, transformacji gospodarczej², szybkiej industrializacji oraz legitymizacji władzy poprzez wyniki rozwojowe. Za idealne państwo rozwojowe, Howell (2006) uważa kraj, w którym elita polityczna jest zdeterminowana, aby wspierać wzrost gospodarczy i transformację ekonomiczną oraz posiada zdolność oraz legitymację do promowania agendy rozwojowej. Zmotywowana przesłankami patriotycznymi, dąży ona do zmodernizowania kraju, podniesienia poziomu życia mieszkańców oraz nadrobienia zaległości rozwojowych wobec gospodarek wysoko rozwiniętych. Komplementarna wobec elity politycznej jest państwowa biurokracja, w szczególności ta jej część, która odpowiada za politykę ekonomiczną i rozwojową oraz reformy systemowe, oraz która posiada wykwalifikowaną kadrę techniczną i menedżerską zdolną do kierowania rozwojem społeczno-gospodarczym kraju.

Niestety powyższe kategoryzacje nie ułatwiają w zbyt dużym stopniu zrozumienia sedna wschodnioazjatyckiego modelu rozwoju. Nie czynią tego również pionierskie opracowania dotyczące koncepcji państwa rozwojowego, gdyż z reguły są analizami konkretnego kraju, a nie szerszymi studiami porównawczymi. MITI and the Japanese Miracle: The Growth of Industrial Policy, 1925-1975 Chalmersa Johnsona traktuje o Japonii, Asia's Next Giant: South Korea and Late Industrialization Alice Amsden opisuje Koreę Południową, a Governing the Market: Economic Theory and the Role of Government in East Asian Industrialization Roberta Wade'a to przede wszystkim studium Tajwanu.

Zadaniem poniższego artykułu nie jest pełne usystematyzowanie cech wschodnioazjatyckiego modelu rozwoju, a tym samym, koncepcji państwa rozwojowego. Niemniej jednak, powinien on służyć jako przyczynek ku temu, gdyż poddaje on analizie główne uwarunkowania polityczne, które uformowały model i stały się jego integralną częścią. Pierwsze pytanie dotyczy typu ustroju politycznego, a zatem warunków systemowych wschodnioazjatyckiego modelu rozwoju. Niewątpliwie jest to zagadnienie o tyle frapujące, iż może mieć szersze reperkusje dla rozwojowo ukierunkowanych elit politycznych

${ }^{2}$ Nie chodzi tutaj o transformację posocjalistyczną, ale o proces zwiększania wartości dodanej w produkcie krajowym brutto $(\mathrm{PKB})$. 
państw słabiej rozwiniętych. Po drugie, jakie znaczenie dla modelu mają instytucje polityczne - zawsze wymieniane jako nieodzowna składowa sukcesu rozwojowego, ale czasami słabo zdefiniowane. W końcu, każde państwo funkcjonuje w określonych międzynarodowych warunkach politycznych. W przypadku historycznych państw rozwojowych te uwarunkowania zewnętrzne miały duże znaczenie.

\section{Ustrój polityczny}

Chociaż z pozoru nie ma bezpośredniego związku pomiędzy rodzajem systemu politycznego a niezbędnym środowiskiem systemowym, w jakim można wprowadzać elementy wschodnioazjatyckiego modelu rozwoju, to takiej korelacji nie można odrzucić a priori. Upraszczając, istnieją trzy główne teorie, próbujące zdefiniować relację pomiędzy typem ustroju politycznego a dynamiką rozwojową; pierwsza neguje związek pomiędzy dynamiką rozwojową a tym, czy dane państwo jest autorytarne czy demokratyczne; druga stwierdza, że autorytaryzm jest lepszym systemem politycznym dla rozwoju społeczno-gospodarczego niż demokracja; trzecia broni demokracji, jako kluczowej dla dynamiki rozwojowej i jakości rozwoju. Robinson i White (1998) podkreślają, że autorytaryzm był powszechnie postrzegany jako korzystny dla przyspieszania rozwoju społeczno-gospodarczego, w całym okresie lat 60., 70., oraz wczesnych lat 80 . XX w., w kontekście nadrabiania zaległości rozwojowych. To przekonanie oparte było na założeniu, że proces zdynamizowania rozwoju wymagał silnego państwa, a demokracjom w ubogich społeczeństwach brakowało tej siły. Istotnie, Hayashi twierdzi, że „przynajmniej w przeszłości, autorytaryzm wydawał się być krótszą ścieżką do [osiągnięcia wysokiego poziomu] rozwoju" (Hayashi, 2010, s. 58), częściowo z powodu łatwiejszej kontroli siły roboczej w procesie uprzemysławiania (poprzez autorytarne praktyki ograniczania praw), a zatem podczas szeroko zakrojonych zmian strukturalnych i transformacyjnych. Przeworski i Limongi (1993) pokazują, że wyższość autorytaryzmu, jeśli chodzi o trajektorię rozwojową może też być dowiedziona z punktu widzenia polityki gospodarczej. Demokracja bowiem z natury rzeczy negatywnie wpływa na strumień inwestycji, ponieważ „generuje eksplozję żądań konsumpcyjnych” (Przeworski, Limongi, 1993, p. 54), a zatem utrudnia akumulację kapitału. „Wzrost gospodarczy wymaga [natomiast] akumulacji kapitału, co z kolei wymaga, aby zasoby zostały przekierowane od konsumpcji do inwestycji” (Haggard, 2004, s. 58). Od połowy lat 80., jednakże demokrację i rozwój społeczno-gospodarczy postrzega się jako komplementarne. „Szersza partycypacja społeczeństwa oraz naciski różnych grup społecznych, jak i zwiększona reprezentacja polityczna kobiet i innych grup dyskryminowanych, powodują, iż reżimy demokratyczne są bardziej wrażliwe na kwestie ubóstwa oraz różne formy dyskryminacji ze względu na płeć, [czy] pochodzenie etniczne, co zmusza je do podejmowania odpowiednich działań zaradczych w ramach podjętych zobowiązań politycznych" (Robinson, White, 1998, s. 7). Demokratyzacja „otwiera przestrzenie socjo-ekonomiczne dla pozytywnych form mobilizacji” (White, 1998, s. 21), co częściowo przekłada się na „osadzoną autonomię" (ang. embedded autonomy) Evansa (1995), w której sugestie różnych grup społecznych brane są pod uwagę przez elity rządzące, a jednocześnie państwo posiada pełną autonomię w podejmowaniu decyzji dotyczących polityki państwa. Wymóg osadzonej autono- 
mii - obecny w analizach koncepcji państwa rozwojowego - mógłby być postrzegany jako rekomendacja dla praktyk demokratycznych. Z drugiej jednak strony, w odniesieniu do koncepcji państwa rozwojowego, tak zwany „stary pogląd”, określany przez White'a (1998) mianem „pesymistycznej perspektywy”, w dalszym ciągu ma wielu zwolenników i opiera się na przekonaniu o pewnej niekompatybilności pomiędzy demokracją i rozwojem, gdyż - cytując Leftwicha (2000, s. 174) - „ta pierwsza jest konserwatywnym systemem władzy, podczas gdy ten drugi jest radykalnym i burzliwym procesem". W literaturze przedmiotu istnieją przykłady demokratycznych i autorytarnych państw rozwojowych. Oczywiście, ani demokracja ani autorytaryzm nie gwarantują skutecznego państwa rozwojowego. Przy zastosowaniu szerokiej definicji państwa rozwojowego, a zatem wykraczającej poza geograficzne ramy Azji Wschodniej, za (w miarę) demokratyczne jego przykłady uznaje się: Botswanę, Malezję, czy Mauritius oraz Japonię (Robinson, White, 1998), czasami też Singapur. W szczególności Amartya Sen propaguje pozytywne skutki rozwojowe demokracji w krajach nadrabiających zaległości rozwojowe, opierając się na przykładach Botswany i indyjskim stanie Kerala (Sen, 1998), a ostatnio także na Bangladeszu (Dreze, Sen, 2013). White (1988) i Leftwich (2000) pozostają niezwykle sceptyczni co do możliwości pojawienia się dodatkowych demokratycznych państw rozwojowych. White (1998, s. 42) dostrzega w tym zakresie kilka ograniczeń: historyczne (wszystkie „stare” państwa rozwojowe były autorytarne i przełom w rozwoju, tj. zwiększenie długookresowej dynamiki, nastąpił wcześniej niż zaprowadzenie demokracji), kontekstowe (projektowanie skutecznych rozwojowych instytucji demokratycznych byłoby zadaniem utopijnym ze względu na ograniczenia polityczne i ekonomiczne, zarówno krajowe, jak i międzynarodowe) i systemowe (demokracja nie jest dostatecznie dobrze wyposażona w instrumenty do generowania szerszego zainteresowania publicznego na rzecz zapewnienia podstawowych dóbr publicznych, ponieważ charakteryzuje się uregulowanym konfliktem między siłami politycznymi, a rezultaty polityczne są wynikiem konkurencyjnych działań ośrodków politycznych). Leftwich (2000) popiera ten pogląd, podkreślając, że brak dużej liczby demokratycznych państw rozwojowych jest wynikiem bardzo szczególnych cech koncepcji. Ponadto, Haggard (1990) uważa, że autorytaryzm może zapewnić państwu niezbędną autonomię w procesie decyzyjnym dotyczącym polityki rozwojowej. Niemniej jednak, jest daleki od twierdzenia, że autonomia rozwojowa państwa jest możliwa wyłącznie w warunkach autorytarnych (Haggard, Moon 1986). W konsekwencji, White (1998, s. 42) przypisuje istnienie demokratycznych państw rozwojowych temu, że charakteryzują się one „autorytarnymi formami reżimu demokratycznego".

Aby lepiej zrozumieć relację pomiędzy reżimem politycznym a państwem rozwojowym, należy wziąć pod uwagę kontekst regionalny, analizując sytuację w kolebce nowoczesnego państwa rozwojowego, a mianowicie, w Azji Wschodniej. Państwo rozwojowe istniało w autorytarnej Korei i na autorytarnym Tajwanie, a także w demokratycznej Japonii. Niemniej jednak trzeba wziąć pod uwagę to, iż zręby państwa rozwojowego w Japonii zaczęto wprowadzać w epoce Meiji i kontynuowano w pierwszej połowie XX w. Podówczas Japonia była imperialną dyktaturą. Ponadto, w okresie super-wzrostu (Maddison, 2007; Johnson, 1999) była przykładem kraju, który Leftwich (2000) opisał jako de facto ,jednopartyjne demokratyczne państwo rozwojowe”, z jedną dominującą siłą polityczną na scenie politycznej. W modelu tym ciągłość polityki rozwojowej była 
zapewniona poprzez brak efektywnej politycznej kontestacji polityki rządu. Co więcej, historyczny model państwa rozwojowego był utrzymywany przez państwową biurokrację, która była główną siłą sprawczą w polityce państwa, podczas gdy demokratycznie wybrani politycy mieli raczej ograniczony wpływ na funkcjonowanie państwa. Tak tę sytuację opisywał Johnson: „Japonią rządzi japońska elita biurokracji państwowej. Rekrutuje się ona z grupy najlepszych absolwentów najlepszych szkół prawniczych w kraju; nominacja następuje w drodze prawnie wiążących egzaminów państwowych, a wybory demokratyczne nie mają na ów proces wpływu. Premier może [co najwyżej] mianować około dwudziestu ministrów i szefów agencji (Johnson, 1982 cit. In Woo-Cumings, 1999, s. 14). Dlatego Camilleri (2000, s. 431) postrzega Japonię jako „hybrydowy system polityczny, w którym impulsy demokratyczne i autorytarne występują na przemian”. W związku z tym, być może słuszne jest twierdzenie, że koncepcję państwa rozwojowego trudno byłoby wprowadzić w warunkach demokratycznych, w których społeczeństwo ma znaczący wpływ na instytucje i politykę państwa. Niemniej jednak, nie jest to całkowicie niemożliwe, gdy spełni się warunek dotyczący braku szerszego konfliktu politycznego (charakterystycznego w ustrojach demokratycznych). Zwolennicy wschodnioazjatyckiego modelu rozwoju czasami przekonują, iż aby skutecznie się rozwijać, należy ograniczyć zdolność społeczeństwa do przeciwdziałania wysiłkom państwa, gdyż działania społeczeństwa są motywowane partykularnymi interesami wynikającymi z przynależności do określonej grupy interesu bądź grupy społecznej. Społeczeństwa, demokratyczne czy nie, są w większości zainteresowane zwiększeniem własnej zamożności w krótkim okresie czasu. „Państwo rozwojowe to umożliwia. Niemniej jednak proces ów nie jest linearny i zrównoważony, co pociąga za sobą sporadyczne spowolnienia w akumulacji bogactwa i niewątpliwie geograficzne i społeczne zróżnicowanie korzyści". Sukces rozwojowy jest bowiem pochodną adekwatnej polityki państwa i rozwiązań instytucjonalnych w długim okresie, a nie wynikiem realizacji indywidualistycznych mikro-celów w krótkim. Tymczasem w demokracji, ,własny interes polityczny polityków i ich partii [niekoniecznie jednakże sprzeczny z ogólnym celem rozwojowym] jest dominującą motywacją do działania. Ci politycy nie są jedynie zainteresowani realizacją własnych [partykularnych] interesów, ale chcą je także osiągnąć w krótkim okresie" (Lijphart, Waisman, 1996, s. 244), co może być sprzeczne z długofalowym interesem narodowym. Johnson (1999) zwraca jednak uwagę na różnice pomiędzy tradycyjnym autorytaryzmem a autorytarnym państwem rozwojowym, bądź takim o ograniczonej demokracji, przywołując kwestię legitymizacji władzy. Podkreśla, iż „źródłem władzy w państwie rozwojowym nie jest ,święta trójca” Webera oparta na tradycji, przesłankach racjonalno-prawnych, czy charyzmie, tylko rewolucyjne nastawienie elit politycznych, wynikające $\mathrm{z}$ determinacji do transformowania społecznego, politycznego i ekonomicznego porządku. Legitymacja [ośrodka politycznego do sprawowania władzy] jest pochodną dokonań [rozwojowych] państwa, a nie sposobu dojścia do władzy" (Johnson, 1999, s. 53). Ponadto ,w prawdziwym państwie rozwojowym [...] biurokraci posiadają taki typ legitymacji, który pozwala im na znacznie bardziej eksperymentalne i niedoktrynalne działania niż w typowym reżimie autorytarnym" (Johnson, 1999, s. 52). Z drugiej jednak strony, chociaż Leftwich (2000) wyróżnia geograficzną, konstytucyjną i polityczną legitymizację władzy, jako możliwe uzasadnienie dla społecznej akceptacji elit rządzących, podkreśla także, że koncepcja ta jest dość abstrakcyjna, a zatem trudna 
do zdefiniowania i zmierzenia, zwłaszcza wśród państw autorytarnych, gdzie dostęp do danych i informacji jest $z$ reguly utrudniony.

\section{Instytucje polityczne}

Leftwich (2000) twierdzi, że dyskusja na temat różnych reżimów politycznych w kontekście ich zastosowania $\mathrm{w}$ warunkach państwa rozwojowego nie rozwiąże problemu ich przydatności, gdyż - zgodnie z opinią White'a (1998) - natura reżimu politycznego nie jest kwestią centralną. Zdaniem Leftwicha (2000) prymat samej polityki, a nie systemu politycznego, jest tutaj kluczowy. „Polityka ma znaczenie, bo wpływa na działania, które to wpływają na kształt państwa, a państwo kształtuje trajektorię rozwojową" (Leftwich, 2000, s. 191). W związku z powyższym, instytucje polityczne mają znaczenie, ale myślenie w kategoriach reżimów politycznych to niewłaściwe podejście do tematyki uwarunkowań wzrostu gospodarczego (Przeworski, Limongi, 1993).

Choć uwarunkowania polityczne wschodnioazjatyckiego modelu rozwoju poddawane są analizie w literaturze przedmiotu często z pozycji systemów politycznych, to coraz częściej uważa się, iż typ reżimu politycznego ma znaczenie drugorzędne, w porównaniu z instytucjami - rozumianymi jako zasady postępowania i związane z nimi ograniczenia (North, 1990) - w procesie kształtowania państw rozwojowych. Analiza uwarunkowań politycznych wschodnioazjatyckiego modelu rozwoju zatem powinna być prowadzona także z perspektywy instytucji politycznych, które choć często powiązane z typem reżimu politycznego, nie są z nim tożsame. Waldner (1999) opisuje instytucje państwa rozwojowego jako instytucjonalne innowacje, które charakteryzują się kilkoma elementami. Po pierwsze, cechy reżimu politycznego, który jest $-\mathrm{w}$ jego opinii - w opozycji do keynesistowskiego klientelizmu, pozwalają na stosunkowo odpolitycznioną politykę gospodarczą, częściowo z powodu braku efektywnej presji ze strony różnych grup społecznych, takich jak robotnicy czy chłopi. Po drugie, ponieważ - cytując Johnsona (1981) - „politycy panują a biurokraci rządzą”, formułowanie długookresowej strategii rozwoju jest dokonywane przez kompetentnych technokratów. Po trzecie, polityka fiskalna jest kontrolowana przez elitę, która jest w pełni oddana idei dynamicznego rozwoju gospodarczego, a zatem wykorzystuje zasoby państwa na rzecz zwiększania produkcji przemysłowej i akumulacji kapitału. Po czwarte, interwencja państwa jest w dużej mierze związana z działaniami, które albo umożliwią sektorowe przekierowanie gospodarki do preferowanych przez państwo gałęzi przemysłu, albo wspierają rodzime firmy w tychże sektorach, w procesie budowania międzynarodowej konkurencyjności (Waldner, 1999, s. 143-144). Dla Donera, Ritchie i Slatera (2005), główne instytucjonalne cechy państwa rozwojowego wyrażają się poprzez aspekty relacyjne (zob. Stubbs, 2009) i istnienie autonomicznej i profesjonalnej biurokracji w ramach agencji nadzorującej czy też pilotującej trajektorię rozwojową. Ta biurokracja tworzy koalicję z prywatnym biznesem i - jeśli to możliwe - robotnikami, aby - cytując Wade'a (1990) -,,zarządzać rynkiem" (ang. govern the market), w celu zdynamizowania rozwoju. Ta percepcja odzwierciedla poglądy Haggarda (2004), który podkreśla rolę „dużych” instytucji, a w przypadku Azji Wschodniej koncentruje się na tym, co określa mianem instytucji „częściowo 
przedstawicielskich” (ang. partially representative) i „delegujących” (ang. delegative). Instytucje częściowo przedstawicielskie dotyczą powiązań pomiędzy sektorem publicznym a prywatnym; instytucje delegujące są agencjami biurokratycznymi o szerokim mandacie w zakresie polityki rozwojowej (Haggard, 2004). Do dużych instytucji we wschodnioazjatyckich gospodarkach charakteryzujących się dynamicznym wzrostem, Haggard (2004) zalicza dobrze systemowo umocowane prawa własności, które umożliwiają efektywną akumulację kapitału, a w konsekwencji wzrost inwestycji. Ponadto, popiera on rozwój „małych” instytucji czy mikro-instytucji, które odnoszą się do wybiórczych interwencji rynkowych i kwestii koordynacji, a zatem kształtują efektywność polityki przemysłowej.

Instytucjonalne pozycjonowanie państwa w centrum działań rozwojowych - za pośrednictwem agencji pilotującej (ang. pilot agency), która jest w dużym stopniu odpowiedzialna za tworzenie i realizację krajowej strategii rozwoju bądź za tworzenie „koalicji” z głównymi aktorami narodowej gospodarki na rzecz rozwoju - wiąże się bezpośrednio z siłą i zdolnościami tego państwa. Historyczne przykłady państw rozwojowych były w opozycji do koncepcji, którą Gunnar Myrdal w swojej analizie rozwojowej Indii i innych państw azjatyckich, określił mianem ,miękkiego państwa” czy też „słabego państwa" (ang. soft state) (Myrdal, 1968)3․ Lankester opisuje słabe państwo Myrdala jako „niezdolne do zaprowadzenia dyscypliny, która jest niezbędna do wdrażania planu rozwoju" (Lankester, 2004, s. 291). Państwo nie jest w stanie zmusić innych aktorów, takich jak społeczeństwo i biznes, do wspierania własnych działań rozwojowych. W rezultacie, wyniki rozwojowe są znikome. Tymczasem, polityka państwa rozwojowego - jak twierdzi Leftwich (2000) - musi być oparta na skutecznej mobilizacji różnych aktorów życia gospodarczego do wspierania trajektorii rozwojowej kierowanej przez państwo. Silne państwo (zob. Katzenstein, 1978; Migdal, 1988, 2001; Deyo, 1987) „może kształtować cele polityczne niezależnie od konkretnych grup [nacisku], może wpływać na zachowanie tychże grup i klas społecznych, [a nawet] zmieniać strukturę społeczeństwa" $(\mathrm{Cu}-$ mings, 1984, s. 7). Silne państwo uosabia: przymus, niezależność wobec konkretnych [...] klas społecznych, interwencjonizm zdolny do „restrukturyzacji” społeczeństwa lub substytucji istniejących struktur i mechanizmów, takich jak rynek (Woo, 1991, s. 2). Państwo rozwojowe nie musi być ,państwem surowym” (koncepcja ta często jest przeciwstawiana koncepcji państwa słabego), w którym mechanizm władztwa to dyktatura nieuznająca kompromisów, ale państwem silnym, zdolnym do stosowania przymusu dla celów rozwojowych. Jego kompetencjami nie są zdolności do represjonowania społeczeństwa, tylko efektywne sterowanie trajektorią rozwojową. Haggard (1990) twierdzi, że ta zdolność wynika ze stopnia odporności na naciski społeczne, spójności struktury decyzyjnej i dostępności instrumentów do osiągania celów politycznych i merytorycznych. Stubbs (2009) przypomina jednak, że w warunkach państwa rozwojowego, silnemu państwu musi towarzyszyć stosunkowo słabe społeczeństwo. Z drugiej jednak strony, przyznaje, że powstawanie państwa rozwojowego nie jest możliwie bez wystarczających zasobów, w postaci środków finansowych, wykwalifikowanej siły roboczej,

${ }^{3}$ Gunnar Myrdal był szwedzkim ekonomistą, laureatem nagrody Banku Szwecji im. Alfreda Nobla w dziedzinie ekonomii w 1974 r. Zajmował się przede wszystkim badaniami nad gospodarkami krajów rozwijających się. Był zwolennikiem silnego, scentralizowanego państwa i planowania w warunkach gospodarki rynkowej. 
a także wiedzy organizacyjnej i technicznej, obecnych z reguły w wyemancypowanych, a nie słabych, społeczeństwach.

\section{Warunki zewnętrzne}

Warunki zewnętrzne niezbędne do powstania silnego państwa opisane przez Migdala (1988) są niezwykle zbliżone do zewnętrznych uwarunkowań, w których powstały państwa rozwojowe, a mianowicie: istnienie zewnętrznych sił politycznych sprzyjających skoncentrowanej kontroli nad społeczeństwem oraz pojawienie się groźby międzynarodowego konfliktu zbrojnego.

W rzeczy samej, część opracowań naukowych skupia się na zewnętrznych czynnikach politycznych, które posłużyły jako katalizatory w procesie powstawania państw rozwojowych. Znaczące sukcesy rozwojowe Japonii, Korei Południowej i Tajwanu niektórzy przypisują nie tyle wewnętrznym uwarunkowaniom systemowym i instytucjonalnym, ile regionalnej geopolityce. Kapitalistyczne państwa rozwojowe Azji Wschodniej tworzono podczas napiętej sytuacji politycznej, związanej z azjatycką odsłoną zimniej wojny. Podobnie jak w innych częściach świata, istniała tam realna groźba konfliktu zbrojnego z użyciem broni atomowej, pomiędzy socjalistycznym blokiem wschodnim, kierowanym przez Związek Radziecki, a następnie regionalnie zdominowanym przez Chiny, a kapitalistycznymi państwami regionu cieszącymi się parasolem ochronnym Stanów Zjednoczonych. Korea Południowa i Tajwan znajdowały się w szczególnej sytuacji, w obliczu zagrożeń ze strony, odpowiednio, Korei Północnej i Chin, roszczących sobie prawo do ich terytoriów. Dlatego też państwa rozwojowe na Tajwanie i w Korei Południowej, jak i w sąsiedniej Japonii, kształtowały się i funkcjonowały w warunkach bardzo poważnych regionalnych napięć politycznych, będących pochodną światowego konfliktu mocarstw i wyścigu zbrojeń. Paradoksalnie, te skomplikowane okoliczności umożliwiły rządom „azjatyckiej trójki” swobodne kształtowanie polityki rozwojowej mającej na celu zwiększanie zasobności, a w konsekwencji po części także zdolności militarnych, niezależnie od ich średniookresowych kosztów społecznych. Zagrożenie bezpieczeństwa państwa stanowiło ważny bodziec dla mobilizacji społeczeństw we wspieraniu elit politycznych.

Z oczywistych względów to Stany Zjednoczone przyjęły, zgodnie z doktryną Trumana, główną rolę w powstrzymywaniu ekspansji komunizmu i równoważenia rosnących wpływów Chińskiej Republiki Ludowej, wspierając kapitalistyczne państwa Azji Wschodniej, zwłaszcza wcześniejszego adwersarza z okresu drugiej wojny światowej Japonię, pozostająca gospodarką „wagi ciężkiej” w regionie, a od zakończenia wojny będącą de facto krajem półperyferyjnym (ang. semi-periphery) wobec USA. Pomoc finansowa i transfer technologii z USA oraz otwarcie amerykańskiego rynku wewnętrznego dla wschodnioazjatyckich dóbr konsumpcyjnych dały potężny impuls dla wzrostu gospodarczego w Japonii, Korei Południowej i na Tajwanie, modernizacji i restrukturyzacji ich gospodarek oraz procesu industrializacji, podczas gdy amerykańskie zaangażowanie wojskowe w regionie stabilizowało w dużym stopniu sytuację polityczną. „Bezpieczeństwo i uwarunkowania ekonomiczne [zatem] były ze sobą nierozerwalnie związane" (Cumings, 1984, s. 17), w okresie dynamicznego wzrostu państw rozwojowych. 
Wszystkie kapitalistyczne gospodarki Azji Wschodniej korzystały z pomocy USA. Szacuje się, że bezpośrednio po drugiej wojnie światowej amerykańska pomoc dla Japonii wyniosła 2,2 mld USD (Serafino, Turnoff, Nanto, 2006), pomoc udzielona Tajwanowi w latach 1951-1968 wyniosła 1,5 mld USD (Otero, 1995), a Korei, od zakończenia wojny koreańskiej do 1975 r., z wyłączeniem pomocy wojskowej, około 6 mld USD (Otero, 1995). Ta pomoc poprzedziła okresy wysokiego wzrostu gospodarczego w państwach rozwojowych Azji Wschodniej. Nie należy jednakże przeceniać jej roli. Choć pomoc była niewątpliwie impulsem początkowym wzrostu gospodarczego, to faktem jest także to, że chociaż Japonia i Tajwan wydały 40 procent środków na rozbudowę i modernizację infrastruktury, to Korea w większości wydała ją na konsumpcję wewnętrzną. Pomimo tej „niegospodarności”, ze względów politycznych pozostała jednakże istotnym odbiorcą funduszy amerykańskich. Jak długo Japonia, Korea Południowa i Tajwan realizowały główny cel polityczny, czyli powstrzymywanie ekspansji komunizmu, tak długo mogły liczyć na polityczne i ekonomiczne wsparcie Stanów Zjednoczonych. Uwarunkowania zimnej wojny ułatwiały zatem mobilizację społeczną na rzecz polityki państwa, a jednocześnie pozostawiały swobodę rządom w określaniu cech polityki rozwojowej i rozwiązań instytucjonalnych, jak długo pozostawały one ogniwem w łańcuchu powstrzymującym komunizm. Warto zwrócić uwagę, iż obecnie kraje chcące zdynamizować wzrost gospodarczy nie mają takiej swobody. Procesy globalizacyjne zwiększyły poziom współzależności ekonomicznej państw, co przy presji aby liberalizować środowisko gospodarcze i otwierać się na świat, spowodowało ich większą podatność na szoki zewnętrzne i ograniczyło możliwości władz centralnych. Niemniej jednak, zwiększyło także dostępność technologii, środków finansowych, inwestycji zagranicznych i rynków międzynarodowych.

Zewnętrzne czynniki polityczne, które kształtowały państwa rozwojowe Azji Wschodniej, nie ograniczają się do zimnej wojny. Cumings (1984), Kohli (1994) oraz Bernard i Ravenhill (1995) wskazują na współzależności regionalne, które wpłynęły na kształt i rozwój wschodnioazjatyckich „krajów nowo uprzemysłowionych” (ang. newly industrialised countries - NIC). Te współzależności wykraczają poza relację określoną przez teorię szyku lotu dzikich gęsi (Akamantsu, 1962) i sięgają wydarzeń XIX w. i polityki kolonizacji półwyspu koreańskiego i Formosy (ówczesna nazwa Tajwanu) przez Japonię. Dlatego też ,procesy uprzemysławiania Japonii, Korei i Tajwanu, nie mogą być traktowane jako odrębne zjawiska, a raczej jako fenomen regionalny, oparty na trzyczęściowej strukturze hierarchicznej składającej się z rdzenia, półperyferii i peryferii” $(\mathrm{Cu}-$ mings, 1984, s. 38). Cumings (1984, s. 8) twierdzi, że ,gospodarczy dynamizm regionu zrodził się wraz z japońskim imperializmem”, gdyż ,zarówno w Korei, jak i na Tajwanie kolonializm japoński przejawiał się nie tylko w formie kontroli wojskowej i policyjnej, ale także poprzez rozwój [społeczno-gospodarczy] pod auspicjami silnego państwa" (Cumings, 1984, s. 10). Kohli (1994) wyróżnił trzy cechy charakterystyczne państwa/ społeczeństwa, które choć postrzegane są jako podstawowe elementy koreańskiego państwa rozwojowego, wywodzą się z japońskiej tradycji kolonialnej: transformacja państwa w wysoce autorytarną, penetrującą organizację, zdolną do kontrolowania, a nawet do gruntownego przekształcenia społeczeństwa koreańskiego; ewolucja cech koalicji zawieranych przez elity rządzące, bardziej zorientowana na produkcję przemysłową w wyniku wzrostu znaczenia produkcji eksportowej; kontrola niższych klas społecz- 
nych. Historia budowania instytucji państwa rozwojowego ma zatem też swój wymiar oparty na interakcji regionalnej.

\section{Zakończenie}

Dokonania rozwojowe niektórych państw Azji Wschodniej w drugiej połowie XX w. można określić mianem spektakularnych. Wschodnioazjatycki model rozwoju, wprowadzany w Japonii, Korei Południowej i na Tajwanie, a obecnie także w innych państwach regionu, jest oparty na koncepcji państwa rozwojowego. Państwo rozwojowe charakteryzuje się przede wszystkim determinacją głównego ośrodka politycznego w działaniach na rzecz nadrabiania zaległości rozwojowych wobec gospodarek wysoko rozwiniętych. Polityka państwa i jego organizacja jest podporządkowana procesowi rozwoju społeczno-gospodarczego.

Wschodnioazjatyckiemu modelowi rozwoju towarzyszą specyficzne uwarunkowania polityczne w zakresie ustroju politycznego, instytucji politycznych i warunków zewnętrznych. Po pierwsze, model może być wdrażany w warunkach zarówno autorytaryzmu, jak i demokracji. Pewną korzyścią autorytaryzmu może być to, iż umożliwia skuteczniejszą niż demokracja izolację od krótkookresowych roszczeń społecznych, które mogą mieć negatywny wpływ na długofalową trajektorię rozwojową. Nie oznacza to, iż w autorytarnych państwach rozwojowych opinie i sugestie społeczeństwa nie są brane pod uwagę. Wręcz przeciwnie, traktuje o tym koncepcja „osadzonej autonomii”, która wyjaśnia, między innymi, mechanizmy konsultacji. Niemniej jednak, autorytarne państwo rozwojowe ma, przynajmniej w teorii, większą swobodę w planowaniu i wdrażaniu polityki rozwojowej. Panuje opinia, iż mechanizmy demokratyczne przekierowują środki od inwestycji do konsumpcji (Przeworski, Limong, 1993); w demokracji wyniki polityki ekonomicznej muszą być natychmiastowe (Lijphart, Waisman, 1996), podczas gdy regularny konflikt między opcjami politycznymi powoduje upośledzenie trajektorii rozwojowej (Leftwich, 2000), gdyż rząd skupia się na walce politycznej, a nie rozwoju społeczno-gospodarczym. Tymczasem, w państwach rozwojowych inwestycje stanowią kluczowy element akumulacji kapitału, polityka państwa musi mieć charakter długofalowy, a rozwój pozostaje jedyną prerogatywą rządu. Niemniej jednak, po wyeliminowaniu szerszego konfliktu politycznego oraz przy specyficznych uwarunkowaniach biurokratycznych, możliwe było efektywne funkcjonowanie państwa rozwojowego w ustroju demokratycznym, o czym dobitnie pokazuje przykład Japonii.

Dlatego też, typ ustroju politycznego nie ma kluczowego znaczenia dla powodzenia państwa rozwojowego. Niezbędne jest natomiast silne państwo, które może istnieć zarówno w ustroju demokratycznym, jak i autorytarnym, choć autorytaryzm jest zapewne lepiej predysponowany, przy spełnieniu licznych dodatkowych warunków. Wschodnioazjatycki model rozwoju charakteryzuje się silnym państwem, odpornym na naciski różnych grup społecznych (w przeciwieństwie do państwa słabego Myrdala (1968)), zdolnym do mobilizowania społeczeństwa i sektora biznesowego na rzecz działań rozwojowych, a nawet zdolnym do „restrukturyzacji” społeczeństwa, w procesie radykalnej transformacji gospodarczej, mającej na celu dynamiczną industrializację. Do kluczowych instytucji silnego państwa rozwojowego zalicza się dobrze umocowane systemo- 
wo prawa własności oraz zdolności do efektywnej interwencji na rynku, w celu korekty procesów ekonomicznych. Państwo bowiem powstaje w centrum procesów transformacyjnych poprzez agencję pilotującą, skupiającą centralną biurokrację ekonomiczną oraz poprzez możność wpływania na innych aktorów i uczestników procesu nadrabiania zaległości rozwojowych.

Niemniej jednak, historycznie, pozycja państwa rozwojowego i zdolność do mobilizacji społecznej związane były z konkretnymi warunkami zewnętrznymi - groźbą konfliktu zbrojnego spowodowaną zimną wojną na kontynencie azjatyckim, a także politycznym i ekonomicznym wsparciem ze strony głównego mocarstwa światowego. Historyczne państwa rozwojowe miały dużą swobodę w kształtowaniu polityki rozwojowej oraz mogły liczyć na wsparcie ekonomiczne i polityczne Stanów Zjednoczonych, co wiązało się ze stabilizowaniem międzynarodowej sytuacji politycznej, pomocą finansową i technologiczną oraz dostępem do największego rynku konsumenckiego na świecie. Jednocześnie, sytuacja międzynarodowa ułatwiała mobilizację społeczną na rzecz polityki państwa. Ta sytuacja, ponadto, zachęcała do zacieśnienia współpracy regionalnej w ramach obozu państw rozwojowych. O ile ta współpraca miała dość specyficzny charakter przed drugą wojną światową; Japonia pod koniec XIX w. podbiła Tajwan, a na początku XX w. - Koreę; o tyle w drugiej połowie XX w. była ona klasycznym przykładem układu w ramach peryferii i półperyferii.

Przyszłość wschodnioazjatyckiego modelu rozwoju nie jest przesądzona. O ile Fukuyama (1992) wieszczył koniec historii i ostateczne zwycięstwo liberalizmu zarówno politycznego, jak i ekonomicznego, a Friedman (2005) przekonywał, że świat jest płaski, o tyle globalny kryzys ekonomiczny, określany mianem Wielkiej Recesji (2008-2009), a w konsekwencji dyskredytacja pewnych rozwiązań instytucjonalnych, dowiodły, iż najskuteczniejszy model rozwojowy drugiej połowy XX w. wciąż może mieć zastosowanie współcześnie, jeśli dopasuje się go do zachodzących procesów globalizacyjnych. Głównym argumentem za jego utrzymywaniem jest zapewne kwestia silnej pozycji państwa. Kraje rozwijające się, które chcą nadrobić zaległości rozwojowe poprzez włączenie się w globalną gospodarkę - wobec czego nie ma realnej alternatywy - muszą posiadać silne państwo, zdolne do wsparcia rodzimego biznesu i negocjowania pozycji międzynarodowej.

\section{Bibliografia}

Akamatsu K. (1962), A Historical Pattern of Economic Growth in Developing Countries, „Journal of Developing Economies", vol. 1, no. 1, s. 3-25.

Amsden A. H. (1989), Asia's Next Giant: South Korea and Late Industrialisation, Oxford University Press, Oksford.

Bernard M., Ravenhill J. (1995), Beyond Product Cycles and Flying Geese: Regionalization, Hierarchy, and the Industrialization of East Asia, „World Politics”, vol. 47, no. 2, s. 171-209.

Camilleri J. (2000), States, Markets and Civil Society in Asia-Pacific, Edward Elgar, Cheltenham.

Cumings B. (1984), The Origins and Development of the Northeast Asian Political Economy. Industrial Sectors, Product Cycles and Political Consequences, „International Organization”, vol. 38, no. 1, s. 1-40.

Deyo F. C. (red.) (1987), The Political Economy of the New Asian Industrialism, Cornell University Press, Ithaca, NY. 
Doner R. F., Ritchie B. K., Slater D. (2005), Systemic Vulnerability and the Origins of Developmental States: Northeast and Southeast Asia in Comparative Perspective, „International Organization”, vol. 59 (Spring), s. 327-361.

Dreze J., Sen A. (2013), An Uncertain Glory India and its Contradictions, Princeton University Press, Princeton.

Evans P. (1995), Embedded Autonomy: States and Industrial Transformation, Princeton University Press, Princeton.

Friedman T. (2005), The World Is Flat: A Brief History of the Twenty-first Century, Farrar, Straus and Giroux, Nowy Jork.

Fukuyama F. (1992), The End of History and the Last Man, Avon Books, Inc., Nowy Jork.

Haggard S. (1990), Pathways from the Periphery, Cornell University Press, Ithaca, NY.

Haggard S. (2004), Institutions and Growth in East Asia, „Studies in Comparative International Development", vol. 38, no. 4, s. 53-81.

Haggard S., Moon Ch.-I. (1986), Institutions and Economic Policy: Theory and a Korean Case Study, Paper presented at the American Political Science Association Convention, Washington, DC.

Hayashi Sh. (2010), The Developmental State in the Era of Globalization: Beyond the Northeast Asian Model of Political Economy, „The Pacific Review”, vol. 23, no. 1, s. 45-69.

Howell J. (2006), Reflections on the Chinese State, „Development and Change”, vol. 37, no. 2, s. 273-297.

Johnson Ch. A. (1981), Introduction: The Taiwan Model, w: Contemporary Republic of China. The Taiwan Experience, 1950-1980, red. J. S. Hsiung, Praeger, Nowy Jork.

Johnson Ch. A. (1982), MITI and the Japanese Miracle: The Growth of Industrial Policy, 1925-1975, Stanford University Press, Stanford.

Johnson Ch. A. (1999), The Developmental State: Odyssey of a Concept, w: The Developmental State, red. M. Woo-Cumings, Cornell University Press, Ithaka, NY, s. 32-60.

Katzenstein P. (red.) (1978), Between Power and Plenty: Foreign Economic Policies of Advanced Industrial States, University of Wisconsin Press, Madison, WI.

Kohli A. (1994), Where Do High Growth Political Economies Come From? The Japanese Lineage of Korea 's 'Developmental State', „World Development”, vol. 22, no. 9, s. 1269-1293.

Lankester T. (2004), 'Asian Drama': The Pursuit of Modernization in India and Indonesia, „Asian Affairs", vol. XXXV(III), s. 291-304.

Leftwich A. (2000), States of Development: On the Primacy of Politics in Development, Polity Press, Oksford-Cambridge.

Lijphart A., Waisman C. (red.) (1996), Institutional Design in New Democracies: Eastern Europe and Latin America, Westview Press, Boulder, CO.

Maddison A. (2007), Contours of the World Economy, I-2030, Oxford University Press, Oksford.

Migdal J. S. (1988), Strong Societies and Weak States: State-Society Relations and State Capabilities in the Third World, Princeton University Press, Princeton, NJ.

Migdal J. S. (2001), State in Society: Studying How States and Societies Transform and Constitute One Another, Cambridge University Press, Cambridge.

Myrdal G. (1968), Asian Drama. An Inquiry into the Poverty of Nations, Penguin Books, Londyn.

North D. C. (1990), Institutions, Institutional Change and Economic Performance, Cambridge University Press, Cambridge.

Otero C. (red.) (1995), Examples of Successful Models of Development. Country Overviews, United States Agency for International Development, Washington, DC.

Przeworski A., Limongi F. (1993), Political Regimes and Economic Growth, "Journal of Economic Perspectives", vol. 7, no. 3, s. 51-69.

Robinson M., White G. (red.) (1998), The Democratic Developmental State: Politics and Institutional Design, Oxford University Press, Oksford. 
Sen A. (1999), Development as Freedom, Oxford University Press, Nowy Jork.

Serafino N., Turnoff C., Nanto D. K. (2006), U.S. Occupation Assistance: Iraq, Germany and Japan Compared, CRS Report for Congress RL33331, 23 March, Congressional Research Service, Washington, DC.

Stubbs R. (2009), What Ever Happened to the East Asian Developmental State? The Unfolding Debate, „The Pacific Review”, vol. 22, no. 1, s. 1-22.

Wade R. (1990), Governing the Market: Economic Theory and the Role of Government in East Asian Industrialisation, Princeton University Press, Princeton, NJ.

Waldner D. (1999), State Building and Late Development, Cornell University Press, Ithaca, NY.

Weiss L. (2000), Developmental States in Transition: Adapting, Dismantling, Innovating, not 'Normalizing', „The Pacific Review”, vol. 13, no. 1, s. 21-55.

White G. (red.) (1988), Developmental States in East Asia, Macmillan Press, Nowy Jork.

White G. (1998), Constructing a Democratic Developmental State, w: The Democratic Developmental State: Politics and Institutional Design, red. M. Robinson, G. White, Oxford University Press, Oksford.

Woo J.-E. (1991), Race to the Swift: The Role of Finance in Korean Industrialization, Columbia University Press, Nowy Jork.

Woo-Cumings M. (1999), Introduction: Chalmers Johnson and the Politics of Nationalism and Development, w: The Developmental State, red. M. Woo-Cumings, Cornell University Press, Ithaca, NY.

\section{Political Conditionality of the East Asian Development Model: The System, Institutions and External Conditions}

\section{Summary}

The article analyses the political determinants of the East Asian development model, focusing on the political system, institutions and external conditions. The model is responsible for spectacular development achievements of some East Asian states and is based on the concept of the developmental state, whose main role is to ensure the developmental caching up with the developed states. The analysis is aimed at answering the question about the preferred type of the political system of the developmental state, defining key institutions for its effective institutionalisation and describing its specific external political conditions.

The analysis shows that the concept can be implemented in countries with democratic and authoritarian regimes. An authoritarian regime may have a better political environment for the purposes of the developmental state, nevertheless the actual genus of the political system is of secondary importance. It is the establishment of relevant and well-functioning institutions, such as property rights and the state's ability to correct the functioning of the market, that is of key importance. The developmental state is a strong state, capable of mobilizing society and the business sector for development purposes. Its position is partly a result of external conditions. Historical development states were created during the Cold War, and the international situation facilitated the mobilisation of societal support and enabled political and economic support of the United States.

Key words: development, political system, institutions, East Asia 
